\title{
Anti-Toxoplasma gondii and anti-Neospora caninum antibodies in capybaras (Hydrochoerus hydrochaeris) from Itu Municipality, São Paulo
}

\author{
Anticorpos anti-Toxoplasma gondii e anti-Neospora caninum em capivaras \\ (Hydrochoerus hydrochaeris) do Município de Itu, São Paulo
}

Juliana Aizawa Porto de Abreu ${ }^{1}$; Felipe da Silva Krawczak ${ }^{1}$; Fernanda Passos Nunes²; Marcelo Bahia Labruna ${ }^{1}$; Hilda Fátima de Jesus Pena ${ }^{1 *}$

\begin{abstract}
${ }^{1}$ Laboratório de Doenças Parasitárias, Departamento de Medicina Veterinária Preventiva e Saúde Animal, Faculdade de Medicina Veterinária e Zootecnia, Universidade de São Paulo - USP, São Paulo, SP, Brasil

${ }^{2}$ Associação Fazenda Vila Real de Itu, Itu, SP, Brasil
\end{abstract}

Received April 5, 2015

Accepted May 6, 2015

\begin{abstract}
Capybaras (Hydrochoerus hydrochaeris) are the largest rodents found in South America. The aim of the present study was to investigate the occurrence of anti-Toxoplasma gondii and anti-Neospora caninum antibodies in 170 free-living capybaras in a residential park area in Itu Municipality, São Paulo State, Brazil. Serum samples were tested by indirect fluorescent antibody test (IFAT) for $T$. gondii (IFAT $\geq 1: 16$ ) and $N$. caninum (IFAT $\geq 1: 50$ ). Among the 170 samples analyzed, $10 \%(17 / 170)$ and $0 \%(0 / 170)$ were seropositive for T. gondii and $N$. caninum, respectively. This study confirms the widespread presence of $T$. gondii and reinforces the role of capybaras in the life cycle of this parasite. Capybaras may not be important as intermediate hosts of $N$. caninum in the studied environment.
\end{abstract}

Keywords: Toxoplasma gondii, Neospora caninum, Hydrochoerus hydrochaeris, capybaras, Brazil, IFAT.

\section{Resumo}

As capivaras (Hydrochoerus hydrochaeris) são os maiores roedores encontrados na América do Sul. O objetivo do presente estudo foi investigar a ocorrência de anticorpos anti-Toxoplasma gondii e anti-Neospora caninum em 170 capivaras de vida livre, habitando em um condomínio fechado no Município de Itu, Estado de São Paulo, Brasil. Amostras de soro foram testadas por meio da Reação de Imunofluorescência Indireta (RIFI) para T. gondii (RIFI $\geq 1: 16$ ) e $N$. caninum (RIFI $\geq 1: 50)$. Entre as 170 amostras analisadas, $10 \%(17 / 170)$ e $0 \%(0 / 170)$ foram positivas para T. gondii e N. caninum, respectivamente. O presente estudo confirma a ampla distribuição de T. gondii e reforça o papel das capivaras no ciclo biológico desse parasita. Provavelmente, as capivaras não têm um papel importante como hospedeiros intermediários de $N$. caninum no ambiente estudado.

Palavras-chave: Toxoplasma gondii, Neospora caninum, Hydrochoerus hydrochaeris, capivaras, Brasil, RIFI.

Toxoplasmosis and neosporosis are caused by obligate intracellular apicomplexan protozoa that are distributed worldwide. Toxoplasma gondii infects any species of homeothermic animal, including humans (DUBEY, 2010). Neospora caninum is also widely seroprevalent in numerous species of mammals and birds (DUBEY \& SCHARES, 2011). Domestic and wild felids are the definitive hosts of $T$. gondii, whereas the domestic dog and other canids are the definitive hosts of $N$. caninum. More studies are

*Corresponding author: Hilda Fátima Jesus Pena. Departamento de Medicina Veterinária Preventiva e Saúde Animal, Faculdade de Medicina Veterinária e Zootecnia, Universidade de São Paulo - USP, Av. Prof. Dr. Orlando Marques de Paiva, 87, Cidade Universitária, CEP 05508-270, São Paulo, SP, Brasil. e-mail: hfpena@usp.br. necessary to determine which species can maintain $N$. caninum in the wild.

The capybara (Hydrochoerus hydrochaeris) is the largest rodent in the world and is distributed throughout Latin and Central America, from Panama to Argentina. It is an herbivore with semiaquatic habitats (OJASTI, 1991). Both anti-T. gondii and anti- $N$. caninum antibodies have previously been described in wild capybaras that live in direct contact with wild and domestic animals in Brazil (CAÑON-FRANCO et al., 2003; YAI et al., 2008a, b; VALADAS et al., 2010; TRUPPEL et al., 2010b). The objective of the present study was to investigate the frequency of anti- $T$. gondii and anti- $N$. caninum antibodies in free-living capybaras that inhabit a residential park in Itu Municipality, State of São Paulo, southeastern Brazil. This residential park is located in an area of 
conserved forest of 484 ha, including four lakes and approximately 400 homes. The most likely contact of these capybaras in this habitat is with dogs and cats, mostly pets, but there is no estimation of their overall numbers in the park.

From December 2012 to May 2013, 170 capybaras (70 males, 84 females and 16 with no recorded sex) were collected in corrals according to Moreira et al. (2013). This capture was legally authorized by the Brazilian agency SISBIO ("Sistema de Autorização e Informação em Biodiversidade") after a severe case of Brazilian Spotted Fever occurred in a child who was bitten by ticks in this locality in September 2012 (KRAWCZAK et al., 2014). The residential park culled its entire capybara population to reduce the Amblyomma cajennense population to minimal levels. Individual blood samples were collected and sent to the laboratory for multiple serological analyses. The sera obtained by centrifugation were stored at $-20{ }^{\circ} \mathrm{C}$ until processing and were individually tested by indirect fluorescent antibody test (IFAT) for anti-T. gondii (CAMARGO, 1974) and anti-N. caninum (DUBEY et al., 1988) antibodies. For $T$. gondii, tachyzoites of the RH strain were used as the antigen, and the cutoff value was $1: 16$. For $N$. caninum, tachyzoites of the NC-1 strain were used as the antigen, and the cutoff value was 1:50. Capybara IgG antiserum was prepared in sheep by the Zoonosis Control Center of the city of São Paulo (CCZ) and was labeled with fluorescein isothiocyanate, as described by Camargo (1964) and Hudson \& Hay (1976). After standardization, the conjugate was used at a 1:1500 dilution for both agents. Positive and negative control sera from previous studies (YAI et al., 2008a, b) were included in all tests. This work was authorized by the Environment State Secretary of the state of Sáo Paulo (authorization no. 96/2012) and was approved by the Ethical Committee of Animal Use of the Faculty of Veterinary Medicine of the University of São Paulo (protocol No. 3104/2013).

Among the 170 samples analyzed, 10\% (17/170) were positive for T. gondii and featured the following titers: 16 in $1(0.6 \%)$, 32 in 5 (2.9\%), 64 in $9(5.3 \%)$ and 128 in 2 (1.2\%). Among the positive animals, $10.7 \%(9 / 84)$ were female, $8.6 \%(6 / 70)$ were male and one did not have a recorded sex. Regarding the age groups, $4.8 \%(3 / 62)$ of the seropositive animals were infants ( $\leq$ six months), $11.4 \%$ (4/35) were juvenile (> six $\leq 12$ months) and $13.7 \%(10 / 73)$ were adults (> 12 months). None of the animals was seropositive for $N$. caninum.

Capybaras are large herbivorous animals; therefore, they likely become infected with $T$. gondii or $N$. caninum by ingesting oocysts excreted by felids or canids, respectively, which contaminate the environment in which they live. This is the first study on the detection of anti-T. gondii and anti- $N$. caninum antibodies in capybaras from the Municipality of Itu, São Paulo State.

Only two investigations have been performed on anti-N. caninum antibodies in capybaras in Brazil. Valadas et al. (2010) found 3\% $(2 / 63)$ seropositivity in animals from São Paulo State. In the same state, Yai et al. (2008b) reported 9.4\% (20/213); however, the authors reported no occurrence of anti- $N$. caninum antibodies in four of the 11 municipalities included in the investigation. Truppel et al. (2010a) reported the molecular detection of $N$. caninum in capybaras (6/26) from Paraná state, suggesting this host could be a natural reservoir. But, despite serological and molecular evidence, viable $N$. caninum has not been isolated from capybaras yet.

In contrast, high seropositivity has been observed for T. gondii in wild capybaras. In the state of São Paulo, Cañon-Franco et al. (2003) reported 69.8\% (104/149) seroprevalence, and Yai et al. (2008a) reported 75\% (48/64) seroprevalence in six municipalities. Truppel et al. (2010b) found 61.5\% (16/26) in capybaras from a park in the city of Curitiba, Paraná state, in the south of Brazil. Moreover, Yai et al. (2008a) confirmed the viability and large distribution of T. gondii in capybara tissues; they succeeded in isolating the parasite from $90 \%$ (36/40) of the seropositive animals bioassayed in mice. The present paper does not corroborate these previous studies because a low occurrence of $T$. gondii was observed. This lower frequency of anti-T. gondii antibodies and the absence of anti- $N$. caninum antibodies may be explained by the different habitats of the capybaras studied. While the capybaras in previous studies lived in the wild and with free migration to other areas, the capybaras in the present study inhabited a residential park with fewer stray cats and dogs and, consequently, lived in an environment less contaminated with oocysts.

In conclusion, our findings reinforce the role of the capybaras in the life cycle of toxoplasmosis in Brazil, but their impact in urban or anthropized environments may be less important than in the sylvatic cycle and more studies are required to investigate the role of capybaras in the epidemiology of $N$. caninum.

\section{References}

Camargo ME. Improved technique of indirect immunofluorescence for serological diagnosis of toxoplasmosis. Rev Inst Med Trop Sao Paulo 1964; 6(3): 117-118. PMid:14177810.

Camargo ME. Introduçáo às técnicas de imunofluorescência. Rev Bras Patol Clin 1974; 10: 143-171.

Cañon-Franco WA, Yai LE, Joppert AM, Souza CE, D’Auria SR, Dubey JP, et al. Seroprevalence of Toxoplasma gondii antibodies in the rodent capybara (Hidrochoeris hidrochoeris) from Brazil. J Parasitol 2003; 89(4): 850. http://dx.doi.org/10.1645/GE-80R. PMid:14533702.

Dubey JP, Hattel AL, Lindsay DS, Topper MJ. Neonatal Neospora caninum infection in dogs: Isolation of the causative agent and experimental transmission. J Am Vet Med Assoc 1988; 193(10): 1259-1263. PMid:3144521.

Dubey JP, Schares G. Neosporosis in animals: the last five years. Vet Parasitol 2011; 180(1-2): 90-108. http://dx.doi.org/10.1016/j.vetpar.2011.05.031. PMid:21704458.

Dubey JP. Toxoplasmosis of animals and man. 2nd ed. Boca Raton: CRC Press; 2010.

Hudson L, Hay FC. Practical immunology. Oxford: Blackwell Scientific Publications; 1976.

Krawczak F, Nieri-Bastos FA, Nunes FP, Soares JF, Moraes-Filho J, Labruna MB. Rickettsial infection in Amblyomma cajennense ticks and capybaras (Hydrochoerus hydrochaeris) in a Brazilian spotted fever-endemic area. Parasit Vectors 2014; 7(1): 7. http://dx.doi.org/10.1186/1756-3305-7-7. PMid:24387674.

Moreira JR, Ferraz KMPMB, Herrera EA, Macdonald DW. Capybara: biology, use and conservation of an exceptional neotropical species. New York: 
Springer Science Business Media; 2013. http://dx.doi.org/10.1007/9781-4614-4000-0.

Ojasti J. Human exploitation of capybara. In: Robinson JG, Redford KH. Neotropical wildlife use and conservation. Chicago: University of Chicago Press; 1991. p. 237-252.

Truppel JH, Montiani-Ferreira F, Lange RR, Vilani RG, Reifur L, Boerger W, et al. Detection of Neospora caninum DNA in capybaras and phylogenetic analysis. Parasitol Int 2010a; 59(3): 376-379. http://dx.doi. org/10.1016/j.parint.2010.05.001. PMid:20470895.

Truppel JH, Reifur L, Montiani-Ferreira F, Lange RR, Vilani RGC, Gennari SM, et al. Toxoplasma gondii in capybara (Hydrochaeris hydrochaeris) antibodies and DNA detected by IFAT and PCR. Parasitol Res 2010b; 107(1): 141-146. http://dx.doi.org/10.1007/s00436-010-1848-4. PMid:20445992.
Valadas S, Gennari SM, Yai LEO, Rosypal AC, Lindsay DS. Prevalence of antibodies to Trypanosoma cruzi, Leishmania infantum, Encephalitozoon cuniculi, Sarcocystis neurona, and Neospora caninum in capybara Hydrochoerus hydrochaeris, from São Paulo state, Brazil. J Parasitol 2010; 96(3): 521524. http://dx.doi.org/10.1645/GE-2368.1. PMid:20020808.

Yai LEO, Ragozo AMA, Aguiar DM, Damaceno JT, Oliveira LN, Dubey JP, et al. Isolation of Toxoplasma gondii from capybaras (Hydrochaeris hydrochaeris) from São Paulo state, Brazil. J Parasitol 2008a; 94(5): 1060-1063. http://dx.doi.org/10.1645/GE-1548.1. PMid:18576842.

Yai LEO, Ragozo AMA, Cañón-Franco WA, Dubey JP, Gennari SM Occurrence of Neospora caninum antibodies in capybaras (Hydrochaeris hydrochaeris) from São Paulo state, Brazil. J Parasitol 2008b; 94(3): 766. http://dx.doi.org/10.1645/GE-1468.1. PMid:18605804. 